\title{
LAND USE/LAND COVER ASSESSMENT IN A SEISMICALLY ACTIVE REGION IN KUNDASANG, SABAH
}

\author{
N. A. Mohd Kamal ${ }^{1 *}$, K. A. $\operatorname{Razak}^{2}$, S. Rambat ${ }^{1}$ \\ ${ }^{1}$ Malaysia-Japan International Institute of Technology, Universiti Teknologi Malaysia Kuala Lumpur, 54100 Kuala Lumpur, \\ Malaysia - afiqahhkamal@gmail.com, shuibrambat@utm.my \\ ${ }^{2}$ Razak Faculty of Technology and Informatics, Universiti Teknologi Malaysia Kuala Lumpur, 54100 Kuala Lumpur, Malaysia \\ - khamarrul.kl@utm.my
}

KEY WORDS: Land Use Land Cover, Geohazards, Change Detection, Remote Sensing

\begin{abstract}
:
Land use development in the mountainous environment must be risk-informed especially in the area highly vulnerable to disaster and extreme climate. Kundasang, Sabah, Malaysia is one of the tourist-demanding areas characterized by mountainous landscape and agriculture activity. The increasing number of tourists and agriculture activity affects the land use exploration. This area is vulnerable to geohazards such as earthquakes and landslides due to its location under seismically active region and complex geological environment. In this study, geospatial technique was used to assess the land use activity in Kundasang, Sabah pertaining to geological risk in this area. The assessment started with the identification of geohazard activities and its associated tectonic features using field investigation and mapping for coherent visualization. Subsequently, multiple high-resolution satellite imageries were used to detect land use changes before and after the disaster. In order to detect the land use change, object-based change detection was applied based on segmentation and object-based classification compared to the classical pixel-based method. The output of this study shows a number of field evidences associated with geohazard features that affecting the land use activities especially build-up area and agriculture land. In conclusion, the combined results provide an important benefit for better understanding the interaction between geohazard activity and landscape patterns in order to support the planning and decision making through spatial analysis and appropriate object-based processing method.
\end{abstract}

\section{INTRODUCTION}

The land-use and land-cover (LULC) dynamic trend in the mountainous environment is a global issue that results from ubiquitous socio-economic driving forces. This region is not only a shelter and sanctuary for flora and fauna species, it also acts as a multifunction; ecological sources, supplies food and buffer against natural hazard. As it is sensitive to climate change, natural disasters and landscape change, mountainous environment should be extremely highlighted on the land use planning and utilization aspects (Poudel and Shaw, 2017).

Land use planning issue have given a massive challenge to mountain system and its community as well as contribution to highly vulnerable geological hazards. Land use activities such as land exploration and excavation for corridor expansion especially in the mountainous environment in the context of infrastructure and agriculture can be hazardous without any proper consideration of environmental impact assessment on the construction and development (Caldwell, 1988). Optimal land use management is essential in order to address the growing population pressure, potential risk issue and booming economic development as well as sustain the mountain development.

Development planning in the mountainous environment should be emphasized the aspect of sustainable development. This region is more susceptible to geohazard such as soil erosion, landslides and rapid loss of habitat regardless of the seismicity level of this region. The major mountain development activities that is rapid development of agriculture and tourism are the main causes of these environmental consequences since these activities contribute as the source of income for the local community. However, increasing number of hillslope development for tourist accommodation facilities and improper agricultural planting methods can potentially induce slope failures and landslides. Therefore, it is vital to understand the landscape patterns and earth surface characteristics for proper land use management and decision-making process (Prakasam, 2010).

To quantify the relationship between land use activities and physical features on Earth's surface, deploying an appropriate remote sensing technology is an essential component in visualizing and interpreting the landscape pattern from real world to digital image format. Applying remote sensing satellite imagery to quantify LULC classification and characterization opens opportunity to improve land use management while sustain the natural resources. Various research has been conducted to map LULC in mountainous environment using several types of satellite sensor offered with different spatial resolution. In a complex spatial area, very high resolution (VHR) satellite sensor is needed to adequately present the LULC characterization with regards to parameter apply. The advancement of remote sensing technology shows the development of high-resolution imagery that improves the spatial resolution within $1 \mathrm{~m}$. the remote sensing system such as IKONOS, Quickbird and Worldview are capable to detect small LULC types in a finer scale (Hong et al., 2010; Yang et al., 2015; Zhou et al., 2008a).

\footnotetext{
* Corresponding author
} 
In image processing, object-based change detection (OBCD) creates multi-pixel features and promotes better proprieties for mapping high resolution imagery and developing high spectral database. In terms of image analysis, this technique provides more information classes compared to the typical pixel-based that used statistical approach (binary method). In fact, objectbased method ignored individual misclassification as the segmentation in its processing generates object of different shape and scale. This segmentation provides similar images from grouping pixel so that it can be classified based on texture, context and geometry. Thus, classification accuracy can be improved as well as change detection analysis results.

This study focuses on assessment of LULC changes characterized by geohazard activities in mountainous environment in Kundasang, Sabah. Considering the number of LULC damage and economic losses in this area with response earthquake event on 5th June 2015 with magnitude of $6 \mathrm{Mw}$ and its cascading geohazards, integrating LULC information with aforementioned geohazards is critically required. LULC information contributes significantly to spatial planning and land management where the visualization in the form of map and statistical data can be used as a tool for decision makers and authorities to interact with public and local community. Previous study has been conducted on the mass movement with particularly to landslides hazards and risk as Kundasang is susceptible to landslides event (Sharir et al., 2017, 2016). Similarly, (Yusoff et al., 2016) focusses on the Light Detection and Ranging (LiDAR) technology in recognizing landslides induced by earthquake in vegetated and rugged terrain.

Therefore, this paper is present the assessment of land use activities in response to earthquake and its cascading geohazard events on 5th June 2015 in Kundasang Sabah. Identification of geohazard features such as tectonic features is done by field investigation and mapping for coherent visualization. Subsequently, multiple high-resolution satellite imageries were used to detect land use changes before and after the geohazard vents. In order to detect the land use change, object-based change detection was applied in this study which highlight the capability of segmentation and object-based classification compared to the traditional pixel-based method

\section{STUDY AREA}

Kundasang is one of the towns in Ranau district which located in the west coast of Sabah and geographically situated in the South-eastern of the Eurasian plate (Sundaland block). Kundasang is located in the South-eastern of Mount Kinabalu with altitude of $1000-2000 \mathrm{~km}$ above sea level. Kundasang is characterized as undulated valley plain on certain places, undulating and mountainous in most places (Yusoff et al., 2016). Desa Dairy Farm, Rose and Strawberry Garden and Kinabalu Pine Resort are some local attractive tourist areas. The Mount Kinabalu, UNESCO World Heritage site predominantly covered the vicinity of the area. Kundasang is populated mostly by the Dusun and small population of Chinese with tourism and agriculture is the main economic activity.
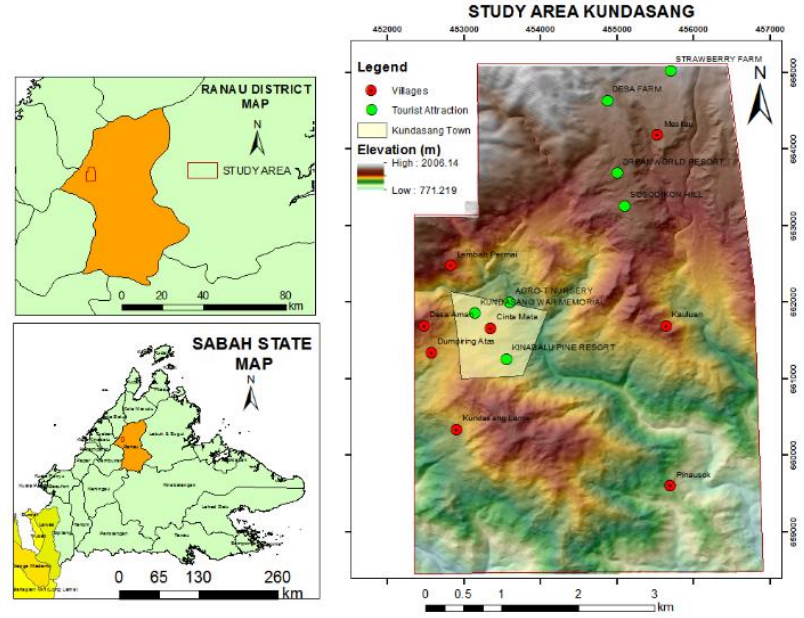

Figure 1. Study Area

Geologically, Kundasang lies in the Crocker formation and Pinousuk culmination in the North, the Ranau Valley in the East and Trusmadi Range and Labuk Highland in the South. The major active faults in Sabah include Mensaban fault, trending northwest-southwest and Lobou-lobou fault, a leftlateral strike fault trending N20E (Tjia, 2007). As a seismically active region, this area is categorized as the extreme geohazardprone area where it is recorded a number of geohazard event had occurred per-year (Roslee and Tongkul, 2018; Sharir et al., 2017; Tongkul, 2017) So far, two major earthquakes have been reported in Kundasang with magnitude of 5.3Mw (1966, depth $52 \mathrm{~km})$ and $5.1 \mathrm{Mw}(1991$, depth $18 \mathrm{~km})$ on Richter scale. One of the fatal earthquakes occurred in June 2015 with $6.0 \mathrm{Mw}$ magnitude hits Kundasang since the last two decades and induced many cascading geohazards in the area.

\section{MATERIALS AND METHODS}

\subsection{Data Acquisition and Pre-processing}

The assessment of land use activity was analysed using postclassification change detection in eCognition platform. This platform mainly used for image processing through segmentation and classification. data source is divided into two parts, primary and secondary data. Figure 2 illustrates the process towards change detection. The primary data mainly involved two high resolution multispectral satellite images, before and after the earthquake event which cover 9 Kundasang villages. These images acquired in Level $1 \mathrm{~A}$ processing was radiometrically corrected. First image is Worldview-2, a product from Digital-Globe Standard Satellite Imagery with $2 \mathrm{~m}$ spatial resolution in multispectral and $0.5 \mathrm{~m}$ in panchromatic acquired on 2014.

The multispectral image provides four additional bands (coastal, yellow, red-edge, and near-infrared (NIR-2) apart from four standard colours (red, green, blue, and NIR). The second image is Satellite Pour l'Observation de la Terre 7, SPOT-7 currently operated by AIRBUS Defense \& Space images with four spectral bands (blue, green, red and near infrared) and a spatial resolution of $1.5 \mathrm{~m}$ (panchromatic) and $5 \mathrm{~m}$ (multispectral) acquired after 4 years of 2015 earthquake. 
In the pre-processing scheme, both images panchromatic is pansharpening to multispectral image for creating a high-resolution coloured image. Next procedure is to attain images to be align and merge. Since both images were in different satellite sources, each flight angle is varied causing misalignment after merging process is done. Therefore, in order to reduce the offset error between images, geometric correction was carried out separately by image-to-image rectification process. The ground control point (GCP) from LiDAR derived orthophoto was used as a base map. These GCPs are applied georectification to both World-view images with a root mean square off less than $1 \mathrm{~m}$ for all images.

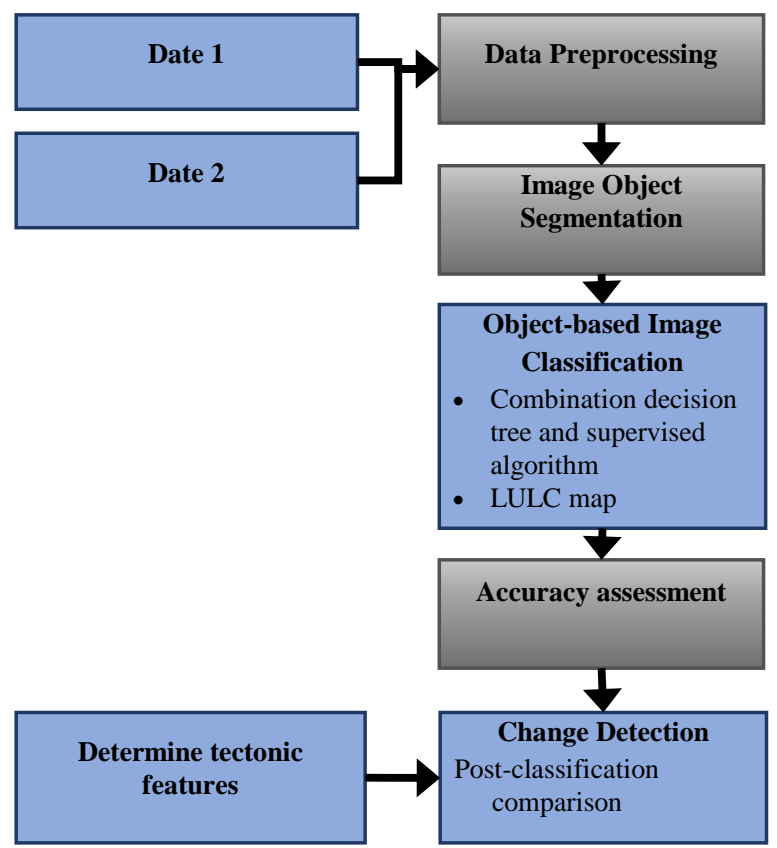

Figure 2. Methodology of the study

\subsection{LULC Classification}

At the beginning of object-based classification, the homogenous pixels of each image need to be combined into an image object so that it can be isolated according to each region. One of the isolation methods is called segmentation process. The image is segmented using multi-resolution segmentation algorithm where each image object in each scale segmentation is correlated to its neighbouring pixels. This segmentation algorithm is made available in eCognition 9 software. The segmentation process requires an optimal scale parameter to provide enormous amount of accuracy for both small and larger objects (Jensen and Clarke, 2005).

Hierarchical-based multiresolution segmentation was applied to merge region for homogenous object-primitives. In multiresolution segmentation, another user-specified input known as shape and colour (compactness and smoothness). These parameters are to determine whether each one of them is heavily weighted for image object creation in homogeneous pixel. In hierarchical-based segmentation, the finest scale parameter was applied so that each pixel minimizes the grouping with adjacent pixels.

The grouped pixels are then applied to the second segmentation process with larger scale which also known as image object level. The process continued until two adjacent image objects exceed its homogeneity, where user-defined the mixed-pixel occur. The scale parameter can be controlled to get the optimal image object (Zhou and Troy, 2008). This is to ensure the neighbourhood pixel can be merged while prioritizing the shape and evenness of image object.

In the classification part, combination of object-based decisiontree classification and supervised classification was applied in the rule set for determining each class. Figures 3 and 4 show the decision-tree classification and supervised classification in one scene with Worldview-2 and another scene with SPOT-7. In the decision-tree classification, image objects were classified into general classes and later divided into more specific classes. A combination of various spectral band (original bands and customized bands ratio) and spatial attribute (area, density and length) was used to identify suitable feature for each class. The description for each feature is presented in Table 1. This feature compares the attributes or histograms of image objects and samples of different classes. It is helpful to get an overview of the feature distribution of image objects or samples of specific classes. The features of an image object can be compared to the total distribution of this feature over one or all image object levels.

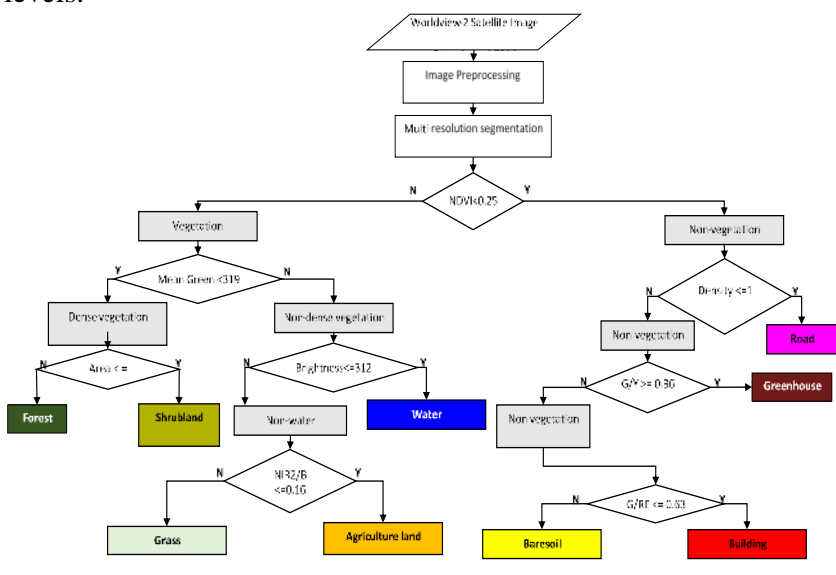

Figure 3. Developed decision-tree to classify Worldview2 imagery

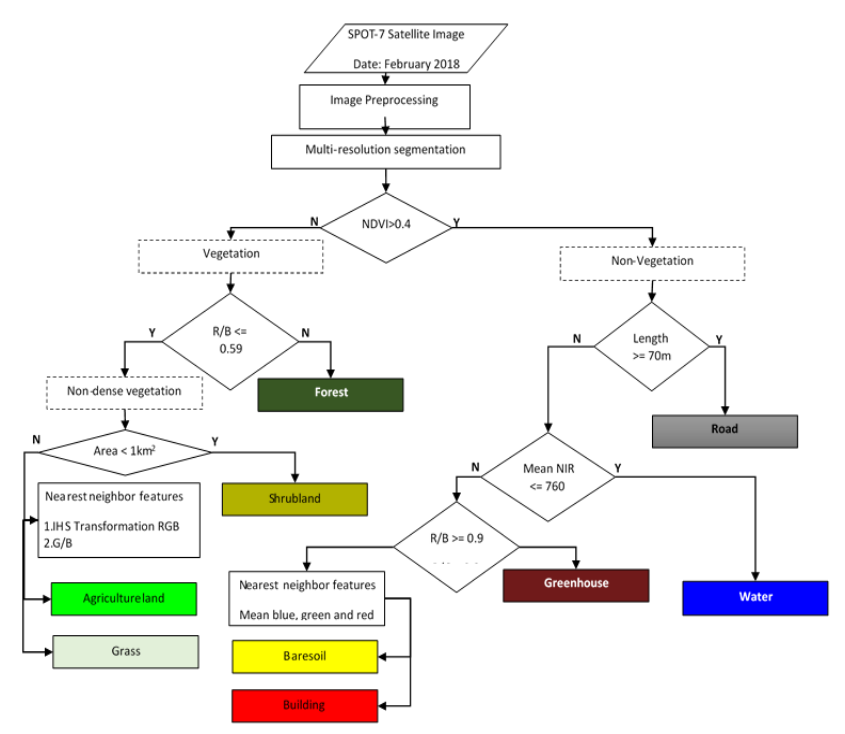

Figure 4. Developed decision-tree to classify SPOT-7 imagery 


\begin{tabular}{|c|c|c|}
\hline Class & Area $\left(\mathbf{k m}^{2}\right)$ & Percentage \\
\hline \multirow[t]{9}{*}{$\begin{array}{l}\text { Date } 1 \\
\text { (Worldview-2) }\end{array}$} & Density & $\begin{array}{r}\text { The distribution in } \\
\text { space of the pixels of an } \\
\text { image object. }\end{array}$ \\
\hline & Area & $\begin{array}{l}\text { The number of pixels } \\
\text { forming an image object }\end{array}$ \\
\hline & Brightness & $\begin{array}{r}\text { Mean values of objects } \\
\text { in all bands }\end{array}$ \\
\hline & G/Y & Mean Green \\
\hline & & $\overline{\text { Mean Yellow }}$ \\
\hline & G/RE & Mean Green \\
\hline & & Mean Red Edge \\
\hline & Nir2/B & Mean NearIR \\
\hline & & Mean Blue \\
\hline \multirow[t]{8}{*}{$\begin{array}{l}\text { Date } 2 \\
\text { (SPOT-7) }\end{array}$} & Length & $\begin{array}{l}\text { Calculated using the } \\
\text { length-to-width ratio. }\end{array}$ \\
\hline & $\mathrm{R} / \mathrm{B}$ & Mean Read \\
\hline & $\mathrm{R} / \mathrm{G}$ & $\begin{array}{l}\text { Mean Blue } \\
\text { Mean Red }\end{array}$ \\
\hline & & $\overline{\text { Mean Green }}$ \\
\hline & $\begin{array}{r}\text { IHS RGB } \\
\text { Transformation }\end{array}$ & $\begin{array}{l}\text { Hue, Saturation, and } \\
\text { Intensity features }\end{array}$ \\
\hline & & $\begin{array}{r}\text { convert RGB colour } \\
\text { space values to HSI } \\
\text { values }\end{array}$ \\
\hline & $\mathrm{G} / \mathrm{B}$ & Mean Green \\
\hline & & Mean Blue \\
\hline
\end{tabular}

Table 1. Features description

The classification process was achieved based on the userdefined threshold values. To decide type of attribute to employ, an "If-Then" algorithm was assigned according to its threshold number for separating the image object from unwanted features. For example, roads have elongated shape compared to other features and forest contains the courses texture than other vegetation. After narrowing down the classes, another two set of supervised classification is applied in SPOT-7 for distinguished between agriculture land and grass; building and baresoil.

\subsection{Tectonic Features}

As the geohazard occurs, as well as geohazard activity continues, it will leave a physical evidence on the earth surface.
Tectonic features in the field shows the active fault movement, mainly in the area appears to be compression between tectonic plate. Meanwhile, other characteristics of crustal structures and tectonic characteristics should be considered. Therefore, the field evidence of geohazard indicator is specifically on tectonic features in response to earthquake event in Kundasang, Sabah on 5th June 2015. The recognition of tectonic features in the field indicates the presence of active faults trending variations in the area.

\subsection{Post-Classification Change Detection}

Multi-temporal post-classification change detection are performed to assess LULC change in the study area before and after earthquake event in four years duration. Firstly, the thematic classes of Date 1 and Date 2 are resegmented using thematic layer resulted from the image classification. The thematic layer is used to distinguish between the boundary of a segmented area so that it does not mix with other segmented objects (Zhou et al., 2008b). Next, a knowledge-based classification was applied using assign-class algorithm which used "if-then" rule for distinguishing between change and no change. Subsequently, the "change" class are divided into possible changes; to-building, to-agriculture, to-baresoil, toshrub and to-water. finally, a total of "from-to" change classes are identified based on existence of subclass algorithm.

\section{RESULTS AND DISCUSSIONS}

\subsection{State of LULC classification}

Figure 5 depicts the classification results for Kundasang area in 2014 (before earthquake) and 2018 (after earthquake) respectively. In LULC map, a total of nine LULC classes are extracted based on Level II of Anderson Land Cover Classification System (Jensen and Clarke, 2005). In 2014, 35\% from the whole study area covered with grass followed by shrub $(26 \%)$ and agriculture land (18\%). Building, greenhouse, road and water covered a small proportion of the entire landscape which under $2 \%$ of coverage. In 2018 , grass cover indicated $1 / 4$ of the whole area, while agriculture land and shrub (24\%). Based on the result, the ratio of agriculture land and building is 4:1 which shows the active agricultural activities while the slow growth of physical development.

\begin{tabular}{llllr}
\hline LULC Class & \multicolumn{2}{c}{2018} & & \\
\cline { 2 - 5 } & Area & Percentage & Area & Percentage \\
\hline Agriculture land & 5.150 & 18.552 & 6.665 & 24.010 \\
Bare soil & 1.882 & 6.780 & 1.272 & 4.582 \\
Building & 0.453 & 1.630 & 1.505 & 5.420 \\
Forest & 2.202 & 7.933 & 2.186 & 7.875 \\
Grass & 9.732 & 35.059 & 8.403 & 30.272 \\
Greenhouse & 0.409 & 1.475 & 0.359 & 1.295 \\
Road & 0.463 & 1.668 & 0.463 & 1.668 \\
Shrubland & 7.346 & 26.465 & 6.728 & 24.239 \\
Water & 0.121 & 0.437 & 0.177 & 0.639 \\
\hline
\end{tabular}

Table 2. Summary of LULC Class 


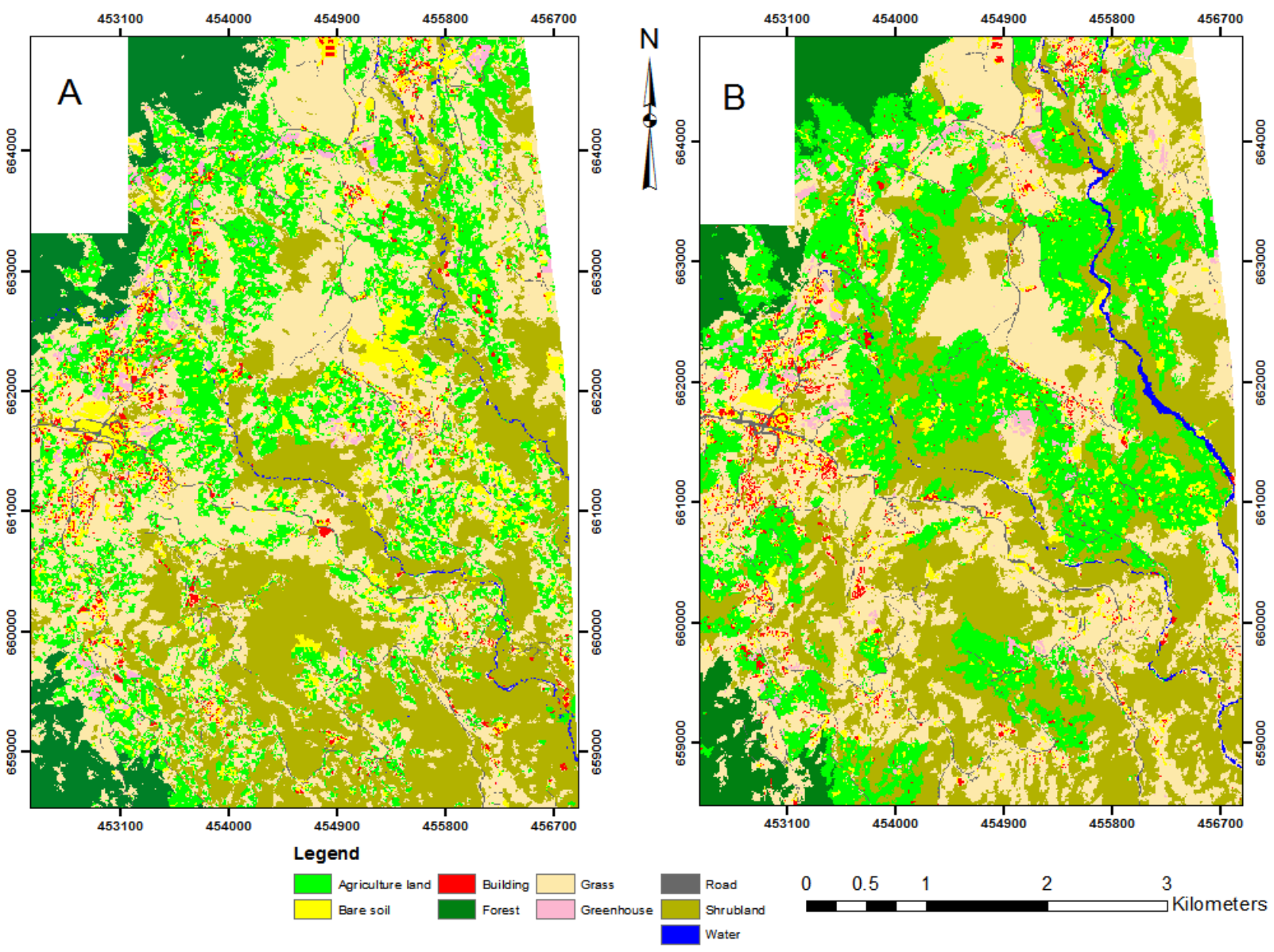

Figure 5. Classification results for Date 1 - 2014 (A) and Date 2 - 2018 (B)

The classification accuracies derived from error matrices are listed in Table 2. By using random stratified sampling method to generate the random points, the overall accuracies for Date 1 and Date 2 are slightly different for the classification maps. an overall classification accuracy in 2014 is $88.3 \%$ while Kappa statistics is 0.85 , which agreed the standard of overall accuracy for land cover map.

According to Story and Congalton (1986), Both producer and user's accuracy for each individual class indicates major classes have higher producer's accuracy while shrub showed a moderate classification performance of $77.14 \%$. unlike 2014 , classification in 2018 a slightly different in the overall accuracy and Kappa (78.75\% and 0.76 respectively. Agriculture land, building, forest, greenhouse and water show an excellent producer's accuracy, while others in acceptable classification performance. It can be seen bare soil class provides the lowest accuracy of $45 \%$ due to misclassification between bare soil and building in the supervised algorithm.

\subsection{LULC Change Detection Results}

Based on Table 4, the change results revealed a considerable change in all classes. The major increase of building which is

\begin{tabular}{ccccc}
\hline \multirow{2}{*}{ LULC class } & \multicolumn{2}{c}{ Date 1 - 2014 } & \multicolumn{2}{c}{ Date 2 - 2018 } \\
\cline { 2 - 5 } & $\begin{array}{c}\text { User accuracy } \\
(\%)\end{array}$ & $\begin{array}{c}\text { Producer accuracy } \\
(\%)\end{array}$ & $\begin{array}{c}\text { User accuracy } \\
(\%)\end{array}$ & $\begin{array}{c}\text { Producer accuracy } \\
(\%)\end{array}$ \\
\hline Agriculture land & 77.03 & 95.00 & 47.06 & 88.89 \\
Bare soil & 95.54 & 81.92 & 100.00 & 45.46 \\
Building red & 80.00 & 100.00 & 100.00 & 90.90 \\
Forest & 91.67 & 85.44 & 81.82 & 100.00 \\
grass & 80.00 & 100.00 & 60.87 & 63.64 \\
Greenhouse & 80.00 & 88.59 & 90.00 & 81.82 \\
Road & 76.25 & 98.39 & 84.21 & 76.92 \\
Shrubland & 96.43 & 77.14 & 80.00 & 100.00 \\
Water & 80.00 & 100.00 & \multicolumn{3}{c}{0.73} \\
\hline Total & \multicolumn{3}{c}{88.38} \\
Kappa
\end{tabular}

Table 3. Summary of accuracy assessment of LULC Class 
about $1.052 \mathrm{~km}^{2}$ which is about $69 \%$ of the cover existed in 2014, while compliment the partly reduction of bare soil in 47\%. The baresoil-buiding change can be seen clearly in Mesilau which located in North of Kundasang where empty land has been upgraded to homestay settlement building. This evidence is supported by Chong et al. (2019) based on the records of local homestay operators interviewed during field study. . On the contrary, the insignificant change occurred in road which considered as no-change, while agriculture land and greenhouse show the nominal increase.

In addition, one-third changes reported in the water body with $31 \%$ increment in the year 2018 as the river area is widening. It can be proven through the situation in Mesilau River at the eastern part of the area where the changes from shrub to water occurred here. Studies show that this area is a former debris flow area that has occurred in response to the cascading geohazard event of earthquake, induced by prolonged rainfall (Yusoff et al., 2016). This river carried several boulders, mud, tree logs and other debris to flow down the river.

\begin{tabular}{lrr}
\hline Class & Area change $\mathbf{( k m}^{\mathbf{2}}$ ) & Percentage \\
\hline Agriculture Land & 1.515 & 22.731 \\
Bare Soil & -0.610 & -47.970 \\
Building & 1.052 & 69.923 \\
Forest & -0.016 & -0.732 \\
Grass & -1.329 & -15.815 \\
Greenhouse & -0.050 & -13.914 \\
Road & 0.000 & -0.031 \\
Shrubland & -0.618 & -9.185 \\
Water & 0.056 & 31.569 \\
\hline
\end{tabular}

\subsection{Change Detection in Tectonic Features}

LULC changes in tectonic features characterized by geological processes and activities which can be used as an indicator to describe the distribution of landforms and dominant land cover. The aforementioned characteristics are also associated to landslides hazard which can be further analysed for LULC change (Van Westen et al., 2003; Varnes, 1984). Table 4 tabulates the list of geological characteristics in the tectonically active area. Four types of fault evidence detected in field; land subsidence, curved road, quarry and huge crack.

\section{4}

A major change from baresoil to building can be seen in the quarry and huge crack area. In quarry section, the existence of Lobou-lobou fault and Mesilau faults coincides each other with trending NE-SW and NW-SE direction respectively (Figure 6). The Lobou-lobou fault dips towards NW cutting through the nearly vertical Mesilau faults (Tongkul, 2017). Meanwhile in the huge crack section, the existence of lineament and cracks can be seen in response to earthquake event on 5th June 2015.

This area experiences the deep-seated landslides causing a ground movement as results of damage in structures. The LULC change map shows the significant change from agriculture to grass in the deflected road due to the active movement of ground surface and the active fault existence trends NE directions. In contrast, as shown in Figure 6, the fault line located in land subsidence at SMK Kundasang which had been abandoned since 2013 due to the active ground movement. There's no change occurred at this area.

A thorough consideration should be taken in these active fault zone. In order to quantify the physical evidence of tectonic activity, other characteristics of crustal structure and tectonic should take into account. (Scales et al., 2017) describes that earthquake hypocenters, focal mechanisms and spatial distribution of earthquake magnitude could be an evidence of tectonic features in the field. Therefore, future research will be conducted by considering the characterization of individual fault segments and especially in the location of densely populated area.

This is because, the physical development in this area should be considered carefully as the active fault is one of the indicators of seismic hazard to occur. As the earthquake occurs, the ground rupture zone will impact the building structure and potentially damage. Understanding the environment protection, ecological and eco-development is essential for reducing vulnerability and environment conservation.

\begin{tabular}{|c|c|c|c|c|c|c|}
\hline \multirow{2}{*}{$\begin{array}{l}\text { Field } \\
\text { Evidence of } \\
\text { active fault }\end{array}$} & \multirow[t]{2}{*}{ Location } & \multirow[t]{2}{*}{ Tectonic features } & \multirow{2}{*}{$\begin{array}{l}\text { Major Change } \\
\text { Class }\end{array}$} & \multicolumn{2}{|c|}{ Geological characteristics } & \multirow[t]{2}{*}{ Date acquired } \\
\hline & & & & $\begin{array}{l}\text { Distance to } \\
\text { fault }(\mathrm{m})\end{array}$ & $\begin{array}{l}\text { Distance to } \\
\text { lineament (m) }\end{array}$ & \\
\hline Land & SMK & Ground rupture & No-change & 30 & 180 & October 2018 \\
\hline Subsidence & Kundasang & & & & & \\
\hline Deflected & $\mathrm{Kg}$ Lembah & normal & Grass-Agriculture & 120 & 90 & June 2015 \\
\hline Road & Permai & fault & & & & \\
\hline $\begin{array}{l}\text { Quaternary } \\
\text { gravel quarry }\end{array}$ & Mesilau & Strike-slip fault & Baresoil-Building & 240 & 150 & June 2015 \\
\hline Huge Crack & Kg Dumpiring & $\begin{array}{l}\text { Fault plane and } \\
\text { deep-seated } \\
\text { landslides }\end{array}$ & Baresoil-Building & 90 & 90 & June 2015 \\
\hline
\end{tabular}

Table 4. LULC Change in tectonic features includes its geological characteristics 


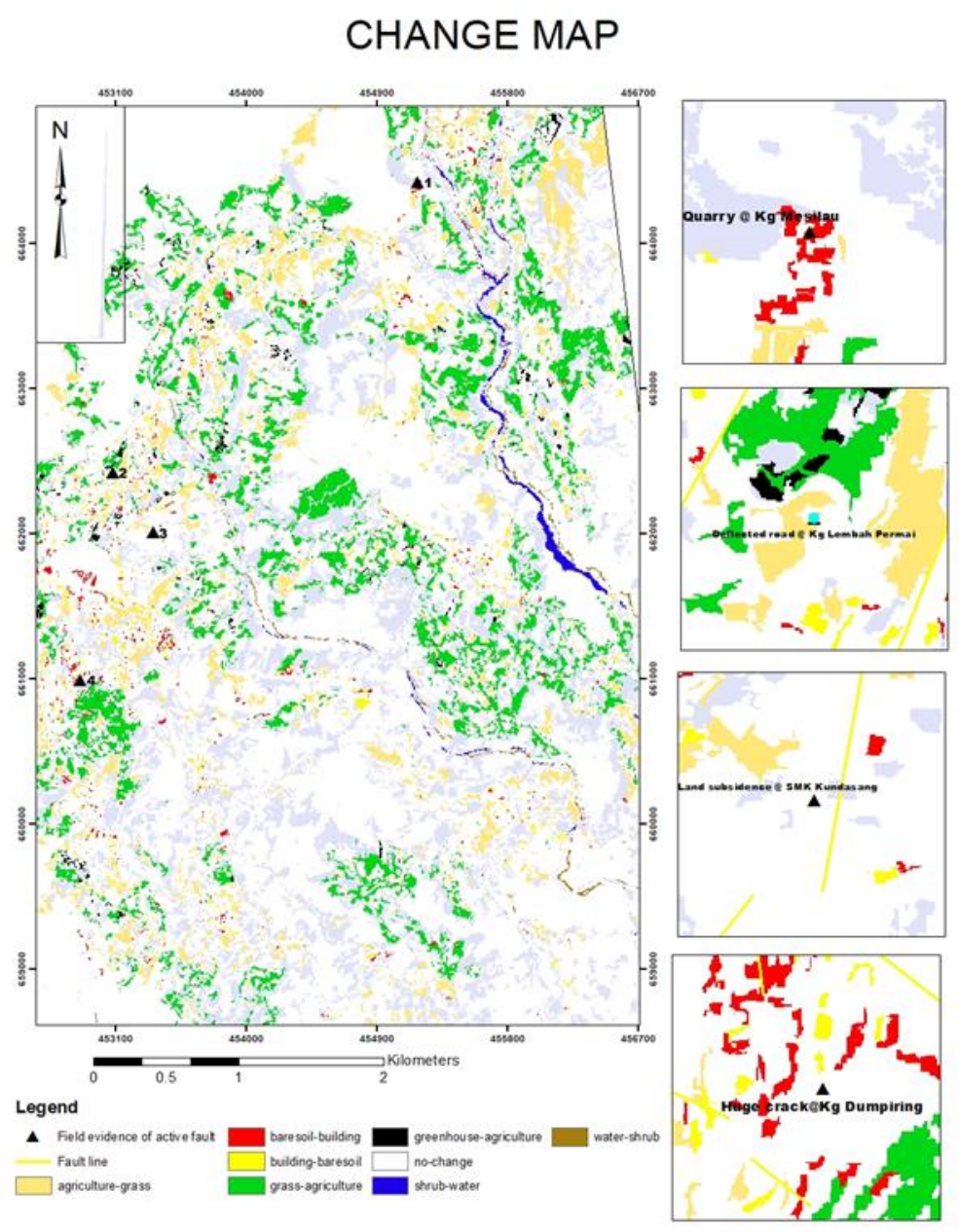

Figure 6. LULC Change and the field evidence of active faults

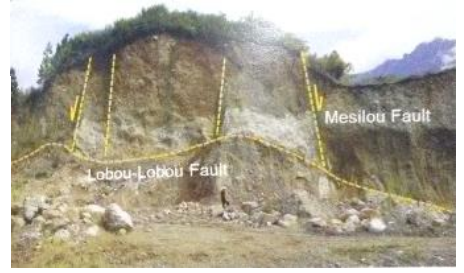

Quarry

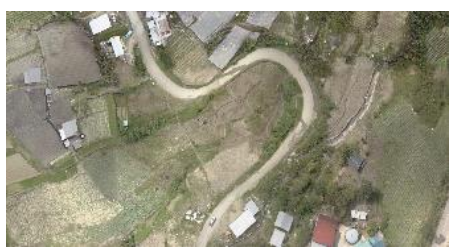

Deflected road

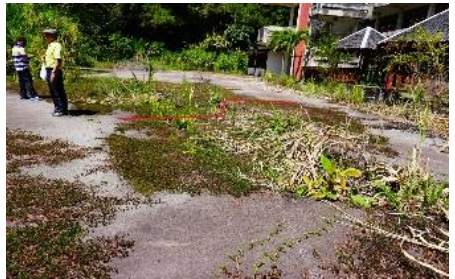

Land subsidence

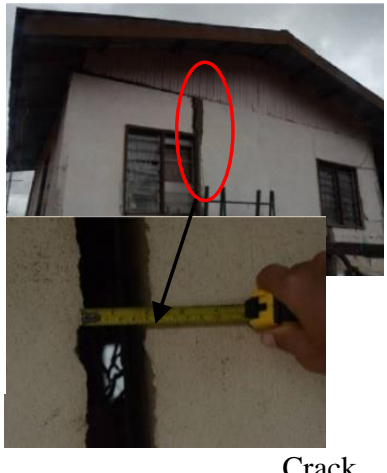

\section{CONCLUSION}

In this study, the rule-set in object-based image analysis for change detection was developed. The rule-set determines features associated to LULC changes by means of decision parameters and available spectral band indices to compute each class. The LULC results from the rule-set dated 2014 and 2018 were compared for change analysis. In the LULC change analysis, it is found that the most significant change occurred from bare soil to building where the accommodation building for tourist increase in this area. In addition, the stream river changes significantly where the debris affect the river stream shape due to the earthquake and extreme rainfall. Further investigation on object-based change detection in tectonic area indicates the existence of minimal changes in the active faults area. In conclusion, this study provides an insight to the land use activity and its distribution in Kundasang area as well as beneficial inputs for town planners and decision makers. Understanding the disaster risk among town planner and decision makers, able to strengthen the governance, investment for resilience and enhance disaster preparedness agenda.

\section{REFERENCES}

Caldwell, L.K., 1988. Environmental Impact Analysis (EIA): Origins, Evolution, and Future Directions. Impact Assess. 6, 75-83. https://doi.org/10.1080/07349165.1988.9725648

Chong, O.N., Wahid SNA, A., Mohd Rani WNM, W., Lumpur, K., Sultan Yahya Petra, J., 2019. From Surviving to Thriving? Evaluating the Resilience of Rural Tourism Businesses in Disaster-Prone Area of Sabah, Malaysia.

Hong, N.M., Chu, H.-J., Lin, Y.-P., Deng, D.-P., 2010. Effects of land cover changes induced by large physical disturbances on hydrological responses in Central Taiwan. Environ. Monit. Assess. 166, 503-520. https://doi.org/10.1007/s10661-009$1019-1$

Jensen, J.R., clarke, K.C., 2005. Introductory digital image processing: A remote sensing perspective, 3rd ed, Upper Saddle River, N.J.: Pearson/Prentice Hall. Taylor \& Francis Group. https://doi.org/10.1080/10106048709354084 
Poudel, S., Shaw, R., 2017. Climate Change and Its Impacts on Land Use/Cover Change and Food Security in Nepal. pp. 253269. https://doi.org/10.1007/978-4-431-56442-3_14

Prakasam, C., 2010. Land use and land cover change detection through remote sensing approach: A case study of Kodaikanal taluk, Tamil nadu. Int. J. GEOMATICS Geosci. 1, 150-158.

Roslee, R., Tongkul, F., 2018. Pakistan Jo urnal of Geology ( PJG ) ENGINEERING GEOLOGICAL MAPPING ON SLOPE DESIGN IN THE MOUNTAINOUS 02, 1-10.

Sharir, K., Roslee, R., Lee, K.E., Simon, N., Tanah Runtuh dan Pemetaan Kerentanan ke atas Cerun Semula Jadi dan Buatan di Kundasang, F., Kamilia Sharir, S., Roslee, R., Khai Ern, L., Simon, N., Sharir, K., Roslee, R., Lee, K.E., Simon, N., 2017. Landslide Factors and Susceptibility Mapping on Natural and Artificial Slopes in Kundasang, Sabah. Sains Malaysiana 46, 1531-1540. https://doi.org/10.17576/jsm-2017-4609-23

Sharir, K., Simon, N.N., Roslee, R., 2016. Regional assessment on the influence of land use related factor on landslide occurrences in Kundasang, Sabah. AIP Conf. Proc. 1784, 060015. https://doi.org/10.1063/1.4966853

Story, M., Congalton, R.G., 1986. Accuracy Assessment: A User's Perspective. Photogramm. Eng. Remote Sensing 52, 397-399.

Tjia, H.D., 2007. Kundasang ( Sabah ) at the intersection of regional fault zones of Quaternary age. Geol. Soc. Malaysia Bull. 53, 59-66.

Tongkul, F., 2017. Active tectonics in Sabah-seismicity and active faults.

Van Westen, C.J., Rengers, N., Soeters, R., 2003. Use of Geomorphological Information in Indirect Landslide Susceptibility Assessment. Nat. Hazards 30, 399-419. https://doi.org/10.1023/B:NHAZ.0000007097.42735.9e

Varnes, D.J. (David J., 1984. Landslide hazard zonation: a review of principles and practice, Natural Hazards. Unesco.

Yang, W.T., Wang, M., Kerle, N., Westen, C.J. Van, Liu, L.Y., Shi, P.J., 2015. Analysis of changes in post-seismic landslide distribution and its effect on building reconstruction. Nat. Hazards Earth Syst. Sci 15, 817-825. https://doi.org/10.5194/nhess-15-817-2015

Yusoff, H.H.M., Razak, K.A., Yuen, F., Harun, A., Talib, J., Mohamad, Z., Ramli, Z., Razab, R.A., 2016. Mapping of postevent earthquake induced landslides in $\mathrm{Sg}$. Mesilou using LiDAR. IOP Conf. Ser. Earth Environ. Sci. 37, 012068. https://doi.org/10.1088/1755-1315/37/1/012068

Zhou, W., Troy, A., 2008. An object- oriented approach for analysing and characterizing urban landscape at the parcel level. Int. J. Remote Sens. 29, 3119-3135. https://doi.org/10.1080/01431160701469065

Zhou, W., Troy, A., Grove, M., 2008a. Object-based Land Cover Classification and Change Analysis in the Baltimore Metropolitan Area Using Multitemporal High Resolution Remote Sensing Data. Sensors (Basel). 8, 1613-1636. https://doi.org/10.3390/s8031613
Zhou, W., Troy, A., Grove, M., Zhou, W., Troy, A., Grove, M., 2008b. Object-based Land Cover Classification and Change Analysis in the Baltimore Metropolitan Area Using Multitemporal High Resolution Remote Sensing Data. Sensors 8, 1613-1636. https://doi.org/10.3390/s8031613

Revised August 2019 